\title{
Traumatic Pseudoaneurysm of the Superficial Temporal Artery: A Case Report
}

\section{Travmatik Yüzeyel Temporal Arter Psödoanevrizması: Bir Olgu Sunumu}

\author{
Mostafa HOSSEINI ${ }^{1}$, Shahnaz MIRI² \\ 1 Tehran University of Medical Sciences, Department of Surgery, Tebran, Islamic Republic of Iran \\ ${ }^{2}$ Tehran University of Medical Sciences, Department of Neurology, Tebran, Islamic Republic of Iran
}

Corresponding Author: Mostafa HOSSEINI / E-mail: md_mostafa_h@yahoo.com

\begin{abstract}
Pseudoaneurysms of superficial temporal artery are very rare and commonly occur as a result of blunt trauma. There are several methods for the diagnosis, but the diagnosis can be accurately made only from a history and physical examination. A 27-year-old man presented with a painless pulsatile mass over his right temporal region after a blunt head trauma. The diagnosis was suspected to be superficial temporal artery pseudoaneurysm. The patient underwent surgical exploration and the mass was resected. Histopathological findings confirmed the diagnosis of pseudoaneurysm. Superficial temporal artery pseudoaneurysm can be easily diagnosed through an accurate history and physical examination alone. Diagnostic methods can be used in complicated cases.
\end{abstract}

KEYWORDS: Trauma, Temporal artery, Pseudoaneurysm

öz

Yüzeyel temporal arter psödoanevrizması çok nadir görülür ve en sık künt travma sonucu olarak ortaya çıkar. Tanı için çeşitli yöntemler vardır, ama sadece bir öykü ve fizik muayene ile doğru tanı konabilir. 27 yaşındaki bir adam, künt kafa travması sonrası, sağ temporal bölgede üzerinde ağrısız pulsatil kitle ile başvurdu. Yüzeysel temporal arter psödoanevrizma tanısı şüphelenildi. Hastaya cerrahi eksplorasyon yapıldı ve kitle rezeke edildi. Histopatolojik bulgular ile psödoanevrizma tanısı doğrulandı. Yüzeyel temporal arter psödoanevrizması doğru bir öykü ve sadece fizik muayene ile kolaylıkla teşhis edilebilir. Komplike vakalarda tanı yöntemleri kullanılabilir.

ANAHTAR SÖZCÜKLER: Travma, Temporal arter, Psödoanevrizma

\section{INTRODUCTION}

Superficial temporal artery pseudoaneurysms (STAP) are rare, and since the first report of STAP in 1740, more than 400 cases were reported in the literature $(1,6)$. Pseudoaneurysm of the superficial temporal artery (STA) usually occurs as a result of blunt trauma to the temporal region (3). The diagnosis is based on history and physical examination, although appropriate imaging modalities such as Doppler ultrasonography, contrast computed tomography, and angiography can help confirm the diagnosis $(1,9)$. The treatment of choice is surgical intervention (3). This report describes a patient with STAP secondary to trauma.

\section{CASE REPORT}

A 27-year-old man was reffered to the surgical department with a painless pulsating mass of his right temporal region (Figure 1). He had a history of a single hit with a stick to his right temple during an altercation 2 months previously. At the time of injury, there was no laceration and no loss of consciousness. The initial swelling subsided 2 weeks after trauma, but a further swelling, $1 \mathrm{~cm}$ in diameter, appeared in this area. On examination, he had a compressible, non-tender, pulsatile mass, anterior and superior to his right ear. By proximal artery compression, the pulsation disappeared. No bruit was audible. Neurological examination was also normal. The patient underwent Computerized tomography (CT) of the head that revealed no acute abnormality or extracranial mass. A traumatic pseduaneurysm of the superficial temporal artery was diagnosed. The patient underwent ligation of proximal and distal ends of the superficial temporal artery and resection of the pseduaneurysm under sedation and local anaesthesia (Figure 2). The patient recovered with no complication after surgery. Histopathological findings confirmed the diagnosis of pseudoaneurysm (Figure 3).

\section{DISCUSSION}

SAT is a branch of the external carotid artery and is divided into three branches as anterior, frontal and posterior partial (1). The anterior branch of STA is the most vulnerable site of pseudoaneurysm secondary to its superficial course and its proximity to the underlying bony structures. The only protective tissue or muscle for STA is temporalis muscle (2). Traumatic aneurysm of the STA was first reported in 1740, and since then, 200 to 400 reports 


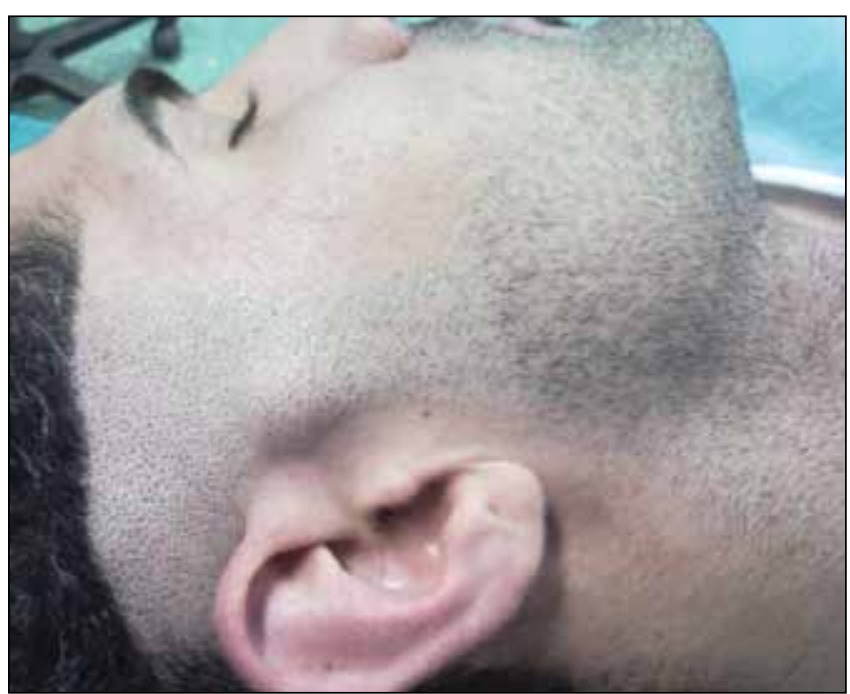

Figure 1: A round $1 \times 1 \mathrm{~cm}$ mass in the right temporal region.

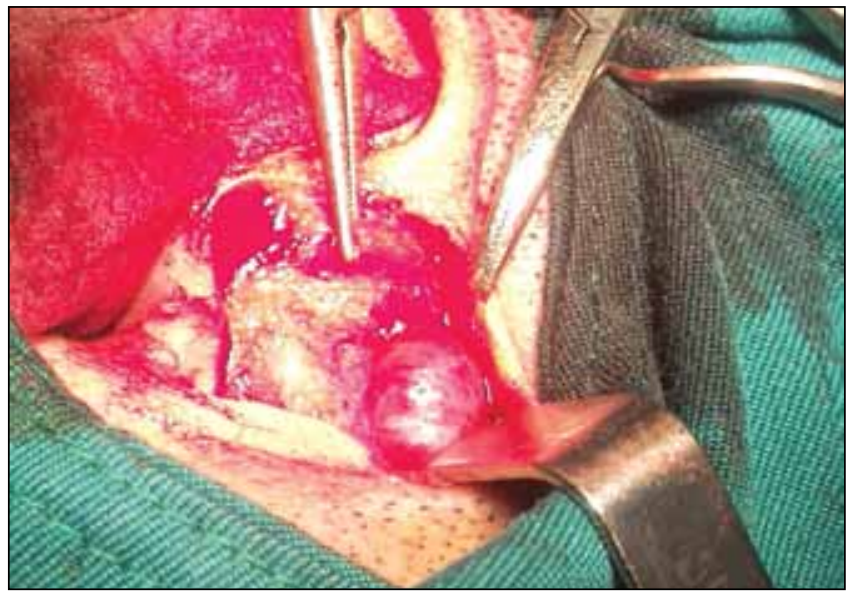

Figure 2: Dissection and ligation of pseudoaneurysm.

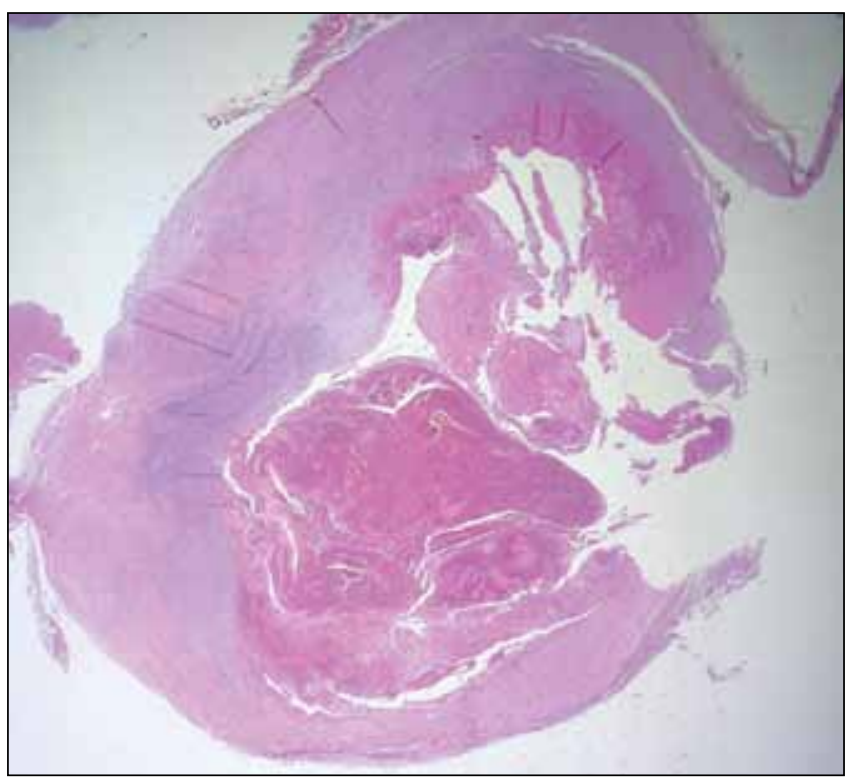

Figure 3: Histopathological finding of the patient, a dilated artery with central thrombus. were found in the literature. STAP accounts for only $1 \%$ of all the traumatic aneurysms and is rare (6). In most of the cases $(75 \%)$, the common cause was blunt trauma including sports injuries, accidents, skull fractures $(6,8)$. Other causes are penetrating injuries (laceration, gunshot, stab wound and surgery), spontaneous formation, and iatrogenic wounds (neurological procedures of skull fixation, hair transplantation, face lift) $(1,4)$.

A pseduaneurysm involves two innermost layers of the vessel. Blunt trauma to the lateral forehead and temporal fossa gives rise to pseudoanerysm. A trauma causes a break in the arterial wall and blood extravasates from it and subsequently hematoma forms. When the artery is injured, a weak preivascular organized fibrous capsule is formed around the hematoma, giving it a painless pulsatile property (5). STAP may be asymptomatic but possible symptoms include headache, ear discomfort, visual disturbance, dizziness, hemorrhage, cosmetic defects and neurologic deficits (4). Symptoms appear typically within 2 to 6 weeks of injury and in rare cases it may arise within 2 to 4 days $(8,4)$.

A through history and physical examination can primarily make the diagnosis (1). Imaging studies including sonography, computed tomography (CT), magnetic resonance imaging, and $C T$ angiography can help confirm the diagnosis (6). All these diagnostic tests may rarely be indicated, and just be required in complicated cases (2). Differential diagnosis is wide and includes hematoma, lipoma, sebaceous cyst, abscess, lymphadenopathy, neuroma of the supraorbital nerve, angiofibroma, arteriovenous fistula, meningocele, encephalocele and lymphoid hyperplasia $(7,10)$. To reduce the possible risks of spontaneous rupture, pain, tenderness, and cosmetic defects, treatment is required (7). Treatment options include conservative treatment with compression, embolization of the affected segment of the vessel, percutaneous thrombin injection under ultrasound guidance, and surgery $(1,9)$. Surgical resection of the pseudoaneurysm and ligation of proximal and distal ends of STA under local or general anesthesia is the method of choice (9). Although a STA pseudoaneurysm is rare, physicians should consider its possibility in a patient with head and facial trauma. It can be easily diagnosed through an accurate history and physical examination alone. Diagnostic methods can be used in complicated cases.

\section{REFERENCES}

1. Ahn HS, Cho BM, Oh SM, Park SH:Traumatic pseudoaneurysm of the superficial temporal artery in a child: A case report. Childs Nerv Syst 26: 117-120, 2010

2. Cadamy AJ, McNaughton GW, Helliwell R: Traumatic pseudoaneurysms of the superficial temporal artery. European Journal of Emergency Medicine 10:236-237, 2003

3. Chen SSH, Prasad SK: Traumatic pseudoaneurysm of superficial temporal artery: A case report. J Clin Ultrasound 37: 312-314, 2009 
4. Choo MJ, Yoo IS, Song HK: A Traumatic pseudoaneurysm of the superficial tempora artery. Yonesi Medical Journal 39(2):180-183, 1998

5. Fukunaga N, Hanaoka M, Masahira N, Tamura T, Oka H, Satoh $\mathrm{K}$, et al: Traumatic pseudoaneurysm of superficial temporal artery. American Journal of Surgery 199(1): e1-e2, 2010

6. Goksu E, Senay E, Alimoğlu E, Aksoy C: Superficial temporal artery seudoaneurysm: Ultrasonographic diagnosis in the ED. American Journal of Emergency Medicine 27:627.e1-627.e3, 2009
7. Parbhu KC, Biesman BS: Traumatic pseudoaneurysm of the superficial temporal artery. Ophthal Plast Reconstr Surg 24(6):501-503, 2008

8. Park IH, Kim HS, Park SK, Kim SW: Traumatic pseudoaneurysm of the superficial temporal artery diagnosed by 3-dimensional CT angiography. J Korean Neurosurg 43:209-211, 2008

9. Quereshy FA, Choi S, Buma B: Traumatic pseudoaneurysm of the superficial temporal artery in a pediatric patient: A case report. J Oral Maxillofac Surg 66:133-135, 2008

10. Vogelaere KD:Traumatic aneurysm of the superficial temporal artery: Case report. J Trauma 57:399 -401, 2004 